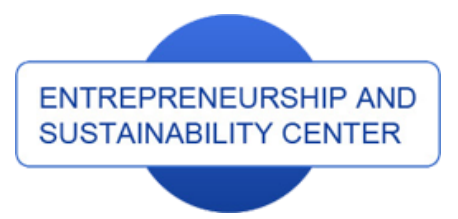

Publisher

http://jssidoi.org/esc/home

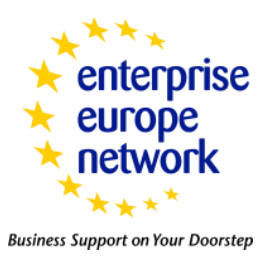

CASPA



1. Clarivate

\title{
SUSTAINABILITY ISSUES OF TERRITORIAL POWER SYSTEMS IN MARKET CONDITIONS
}

\author{
Evgeny Lisin $^{1,2}$, Galina Kurdiukova ${ }^{3}$, Natalya Ketoeva ${ }^{4}$, Joana Katina ${ }^{5}$ \\ ${ }^{1}$ National Research University Moscow Power Engineering Institute, Krasnokazarmennaya 15, Moscow, Russian \\ Federation \\ 2 Prague Business School, Werichova 29, 15200 Praha 5, Prague, Czech Republic \\ ${ }^{3}$ National Research University Moscow Power Engineering Institute, Krasnokazarmennaya 15, Moscow, Russian \\ Federation \\ ${ }^{4}$ National Research University Moscow Power Engineering Institute, Krasnokazarmennaya 15, Moscow, Russian \\ Federation \\ ${ }^{5}$ Vilnius University, Institute of Computer Science, Didlaukio 47, LT-08303 Vilnius, Lithuania
}

E-mails:1,2 lisinym@mpei.ru ; ${ }^{3}$ kurdiukovagn@mpei.ru ; ${ }^{4}$ ketoevanl@mpei.ru $;{ }^{5}$ joana.katina@mii.vu.lt

Received 12 August 2018; accepted 15 December 2018; published 30 December 2018

\begin{abstract}
The paper discusses the issue of improving the management system of the energy complex sustainable development at the territorial level from the perspective of ensuring energy security. It proposes the management models of the electric power and heat supply territorial systems development that allow taking into account current trends of expanding the use of market mechanisms to manage territorial energy production and to ensure a balance of interests of management subjects at various organizational levels. Based on a multidimensional statistical analysis for selected groups of Russian regions, it gives recommendations on choosing a priority strategy to reduce the energy intensity of the gross regional product.
\end{abstract}

Keywords: territorial formation; electric power and heat supply systems; sustainable development, energy strategy; market mechanisms; balance of interests

Reference to this paper should be made as follows: Lisin, E.; Kurdiukova, G.; Ketoeva, N; Katina, J. 2018. Sustainability issues of territorial power systems in market conditions, Entrepreneurship and Sustainability Issues 6(2): 1041-1052. http://doi.org/10.9770/jesi.2018.6.2(38)

JEL Classifications: Q41, Q48, C78

\section{Introduction}


The International Journal

ENTREPRENEURSHIP AND SUSTAINABILITY ISSUES

ISSN 2345-0282 (online) http://jssidoi.org/jesi/

2018 Volume 6 Number 2 (December)

http://doi.org/10.9770/jesi.2018.6.2(38)

Ensuring energy security is a major task of national economic importance, the solution of which is one of the priorities of the state's economic activities. The state as a subject of management has an energy function in the form of a set of areas of economic activity aimed at ensuring the reliable functioning and sustainable development of territorial power supply systems, forming markets of energy resources and products and regulating legal relations of their participants and price limits for the goods and services (Blum et al., 2012; Goldthau et al., 2012; Ang et al., 2015; Štreimikienè et al., 2016; Augutis et al., 2017; Newbery et al., 2018).

The adopted market model of power system management, peculiar to territorial entities of Russia with an open type of power supply systems, requires coordination of the development strategies of its facilities on the part of the energy providers that perform their management and the territorial bodies of state administration in order to ensure the necessary level of energy security to respond to external and internal challenges of reliability and efficiency of integrated power supply to local consumers in the medium and long term (Balitskiy et al., 2014; Chernenko, 2015; Lisin et al., 2015; Strielkowski et al., 2016; Tvaronavičienė 2018; Brożyna et al., 2018).

The conflict of interests caused by the market and expressed in the difference of ideas about the efficiency of the power supply service at different levels of management of its facilities (region and energy providers) leads to a mismatch of the management system of territorial energy production. While the criterion of energy efficiency on the part of the state is operating economy (the most efficient use of natural fuel and energy resources, the low cost of energy production) in the context of ensuring a given level of reliability, the criterion on the part of energy providers is profitability, that is, the compliance of economic objects with a competitive technological infrastructure that allows them to extract income in various trade sectors of the energy markets using the market forces (Wüstenhagen et al., 2007; Goldthau et al., 2012; Salas-Fumás et al. 2016; Tvaronavičiené 2017; Razminienè, Tvaronavičienė 2017; Rausser et al., 2018; or Kashintseva et al., 2018, Shakhovskaya et al., 2018).

Currently, when shaping the regional energy policy by the bodies of state administration of the energy complex in Russia, the interests of territorial energy providers are not taken into account, which leads to ineffective mechanisms for implementing energy programs, and the conditions outlined in the energy strategy under which the energy providers will be able to fulfill the government's requirements become unreachable (Lisin et al., 2014; Hughes et al., 2013; Lisin et al., 2015; Bilan et al., 2017).

In the context of the ongoing liberalization of economic relations in the energy sector and the expansion of the use of market-based management mechanisms, comprehensive implementation of the strategic priorities of the state energy policy requires improvement of the management system of the energy sector development from the perspective of ensuring effective interaction of government bodies with market participants and self-regulating organizations that are subjects of management at various organizational levels. Adequate reflection of the interests of management entities is the basis for the formation of a set of criteria for decision making in regard to development and functioning of territorial power systems.

\section{Improving the management model of the territorial electric power supply system}

To develop a management model of the electric power supply system development at the territorial level, we will conduct a functional and component decomposition of the management organization of its production subsystems, heat and power supply systems. 
The basis of the power supply system management at the territorial level is the developed scheme and program for the development of the power industry in the region for a long-term period. The following regulatory documents are used in this regard (Energy Strategy of Russia, 2014; Lisin et al., 2018a; Lisin et al.m 2018b):

- documents of territorial planning in the field of energy production,

- rules for technological connection of consumers,

- regional program of energy saving and energy efficiency improvement,

- guidelines for power systems design,

- methodological recommendations for the development of a scheme and program for the development of the electric power industry of a country subject for a 5 -year period.

The background information for the development of a scheme and program for the development of the region electric power industry is as follows (Proskuryakova, 2017; Strielkowski et al., 2017):

- forecast of electric energy demand,

- information on applications for technological connection,

- the scheme and program for the development of the unified energy system (UES) of the country, as well as reports on its functioning,

- proposals of the UES system operator.

The scheme and program for the development of the electric power industry in the region makes it possible to form an investment program for the development of territorial electric power industry facilities. In this case, the existing model of managing the power supply system development has the following disadvantages:

- there is no consideration of the strategies and programs of innovative development of territorial generating companies, which leads to the inconsistency of the program with objective trends in the development of the industry in market conditions, and further causes a mismatch of power supply system management at the territorial level,

- there is no consideration of the future development of heat supply systems associated with operating modes with power supply systems, when organizing integrated power supply to consumers, as well as being combined by the complex interrelation of heat and electricity as goods,

- there is no specialized control over the compliance of the developed scheme and the program for the development of the electric power industry with methodological recommendations.

To eliminate these disadvantages, the authors proposed a model for managing the power supply system, shown in Figure 1. 


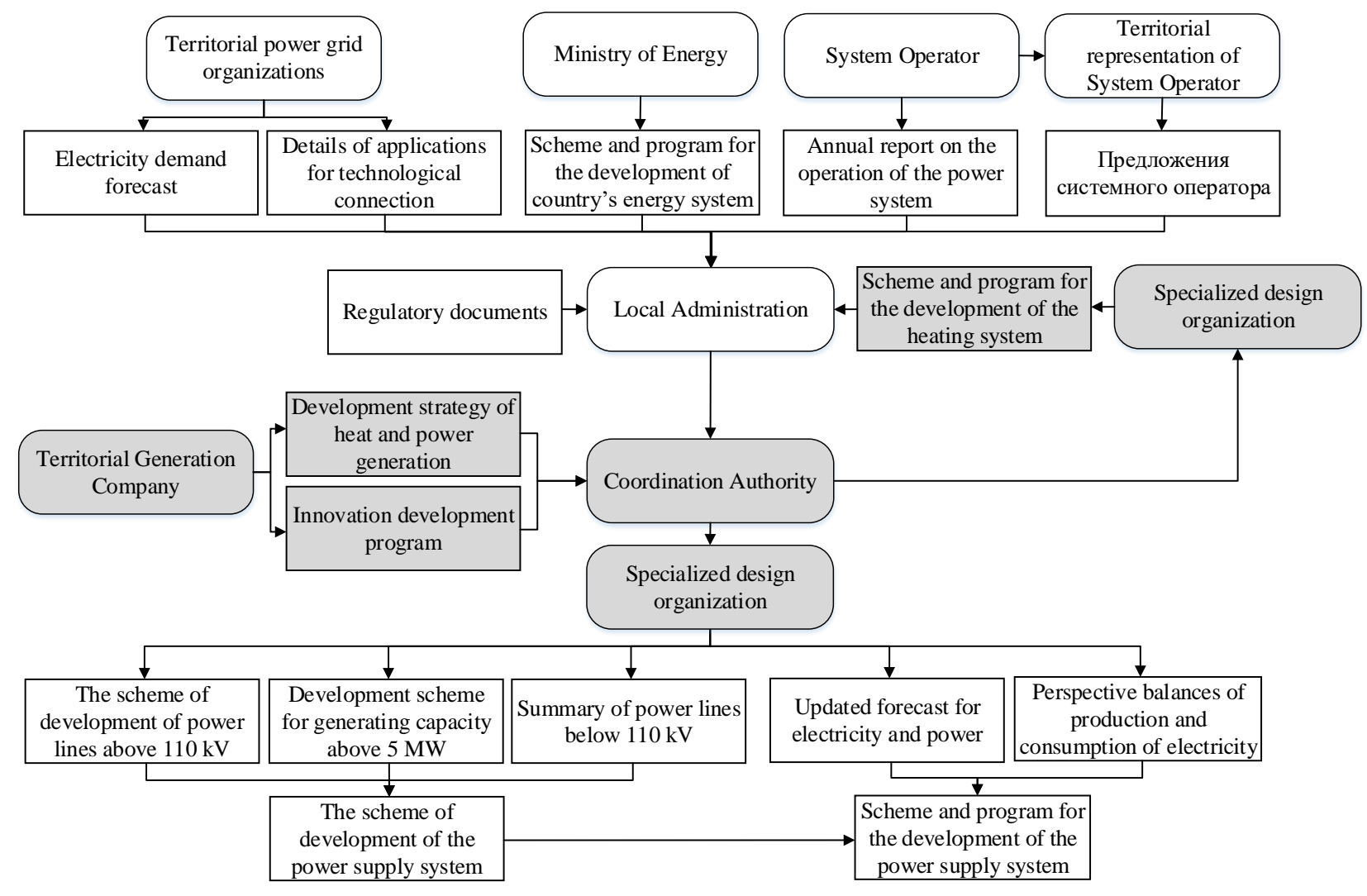

Figure 1. An improved model for managing the power supply system development of a territorial entity Source: own development

Improving the quality of management will be facilitated by the creation of a coordinating management body that will allow coordination of management at various organizational levels between territorial executive authorities and territorial generating enterprises, adequately reflecting the interests of management subjects, both in the field of electric power and heat supply. Also its creation will allow:

- carrying out joint planning of the development of heat and electric power supply systems,

- ensuring the development of integrated power supply of a territorial entity on the basis of an economical combined production of energy products,

- improving the quality of schemes and programs for the development of heat and electric power supply systems based on the allocation of specialized design organizations.

\section{Improving the management model of the local heat supply system}

In contrast to the management of the power supply system, management of the heating system development is in fact fully implemented at the territorial level. Herewith, there are three main types of heat supply management system (Lisin et al., 2016; Lisin et al., 2017; Stennikov et al., 2016):

- based on administrative management, when the heat supply company submits to the administration of the territorial entity, 
- based on private management, when the heat supply company is in private ownership (in particular, of the territorial generating company),

- based on a concession agreement, when the assets of the municipal heat supply company is transferred to trust management; at the same time, the administration retains property rights, but it does not participate in the management of the heat supply company.

The administration of the municipal entity performs the functions of management of municipal heat supply companies. The main criterion for management is budget efficiency, while ensuring affordable heat for consumers. At the same time, the administration also often represents consumers, exercising direct management of budget organizations and enterprises operating the available housing.

Forming the tariff for thermal energy, it actually determines the cost of heat for its own consumption. Therefore, the tariff for heat of the municipal heat supply companies will almost always be lower than that the one established by the regional energy commission. In turn, this affects the underfunding, reducing the reliability of the heating system and the quality of heat supply to consumers. Also, a change of administration can lead to a reorganization of a heat supply company due to its unprofitability (Lisin et al., 2017; Li et al., 2015; Borelli et al., 2016).

Opposite according to the management criterion of municipal heat supply companies are private heat supply companies whose task is to ensure the wealth of owners, an indicator of which is the return on equity, which characterizes the income of shareholders. This management criterion assumes an increase in the price of heat while reducing the costs of production and sale of heat energy. Hence, this model of management contributes to the increase in value added through the implementation of measures to improve the quality of energy supply to consumers and the introduction of new technologies, allowing them to implement energy saving and energy efficiency programs. The cost of heat will be higher than that of municipal heat supply companies, but in general, the reliability and quality of heat supply to consumers increases. At the same time, this management model becomes relevant only when full payment is made (or approached to it) of heat by consumers, in other words, the operation of the heat market with a free pricing mechanism (Lisin et al., 2016; Paiho et al., 2015).

An intermediate management option is to implement it on the basis of a public-private partnership mechanism, which in this case implies the conclusion of a concession agreement by the municipal administration with an entrepreneur. Within the agreement, the management of the heat supply company is transferred to a private person who attracts investments to resolve issues of technological modernization of fixed production assets and improve the quality of heat supply in order to make a profit. At the same time, the municipality retains property rights. In this case, the management criterion, on the one hand, is the profitability of investments, on the other hand, it is the attraction of private investments to increase the reliability and economy of heat supply, as well as reduce budget expenditures. The multiplicity of management criteria leads to the need to balance the interests of the state and business.

Also, a significant drawback of management on the basis of concession agreements is the lack of economic incentives for an entrepreneur to direct profits to the capitalization of municipal property. Thus, a large part of the profit is spent on increasing private property, while the municipal one does not actually develop. In turn, often a change in administration leads to the seizure of municipal property and its return to administrative management due to the absence of other mechanisms of influence. Thus, the previously created heat supply infrastructure is lost.

Heat supply management is influenced by heat consumers with whom heat supply companies enter into heat supply agreements. At the same time, in the centralized heat supply systems, the main consumer is available 
housing. The interaction of end users with heat supply companies is carried out through a management company operating available housing that does not have an economic interest in energy saving, and the installation of appropriate accounting equipment is an additional expense. Thus, the interests of the consumer as a buyer in the heat market are not actually represented (Lisin et al., 2017; Postnikov et al., 2018).

An improved model of the heat supply system management, which allows taking into account the above identified drawbacks, is presented in Figure 2.

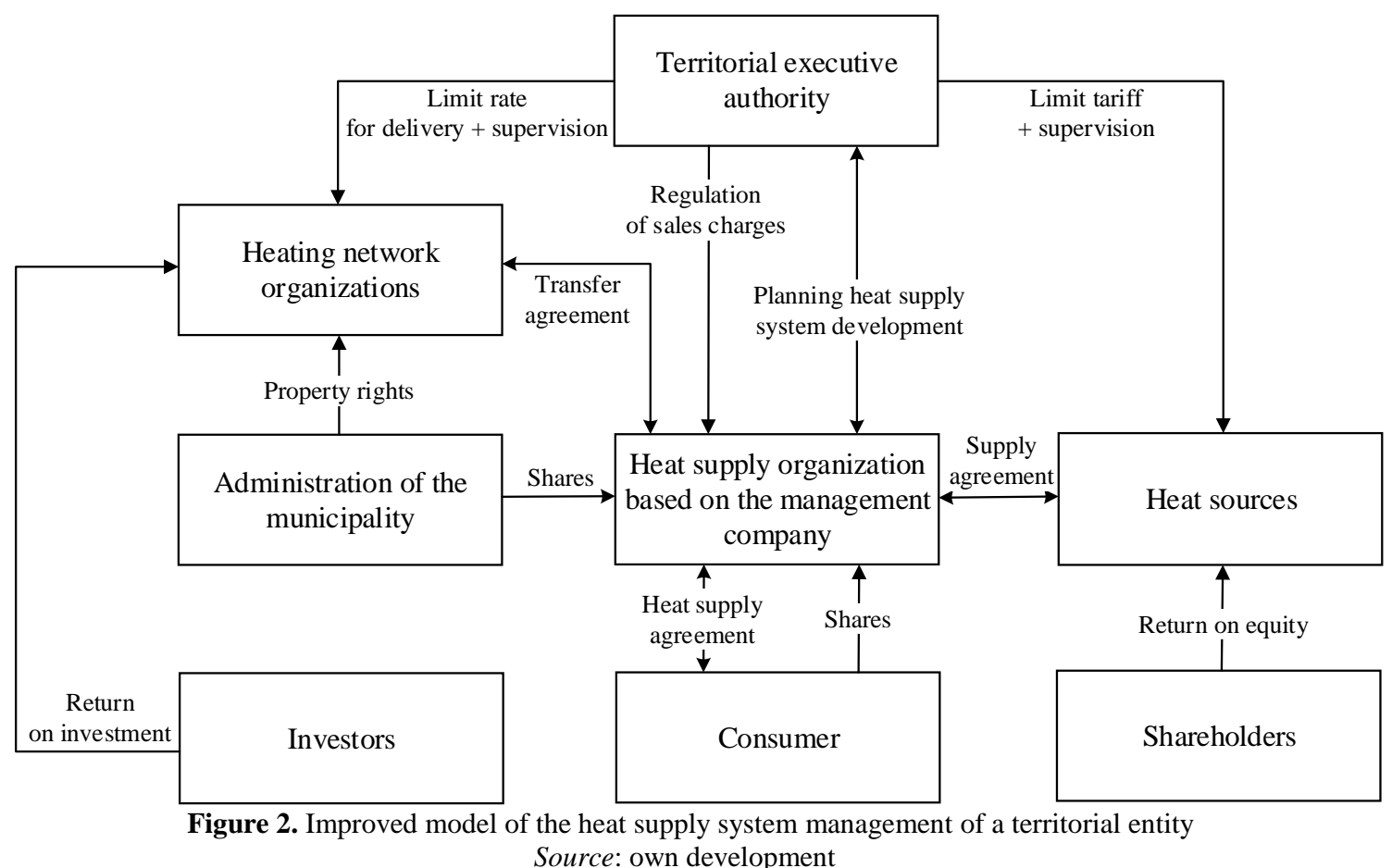

The proposed management model involves creation of a heat supply company on the basis of the management company and implementation of the following activities:

- incorporation of the management company at the expense of the owners of residential premises and the administration of the municipal entity,

- transfer of the heat supply system management to the management company, as well as determination of criteria for the choice of heat suppliers,

- provision of the management company with the long-term planning function for the development of the heat supply system and the development of investment programs to reduce heat consumption,

- securing the management company of the function of distributing funds between heat producers and heat supply companies.

It is also assumed that the heat supply companies will be under municipal administration or operate on the basis of concession agreements, when the property rights are reserved for the administration. In this case, the management company can also be a concessionaire and perform the functions of managing the heat supply company, exercising control over the operation of the heating networks. This is especially advisable when there is a local natural monopoly in the field of heat transport. 
It is advisable to allocate heat sources to individual enterprises and to share them, which will lead to an improvement in the heat supply management system through the development of competition among heat producers. Accordingly, access to heating networks shall be organized under the same conditions. Such an approach allows solving the problem of loading by heat supply companies operating heating networks and their own heat sources, despite the most economical loading options.

Consumers realize their economic interests through the incorporation of a management company representing them in the heat market. Thus, a market buyer is formed which is interested in reducing heat consumption. At the same time, only the management company is liable to consumers, which also improves the quality of management.

\section{Proposing a methodology for choosing a priority strategy for improving energy security at the territorial level}

The energy strategy provides for an individual approach to the development of power supply systems of the country's regions from the perspective of ensuring energy security. It is based on the volume and structure of demand for primary and transformed energy, estimated using a forecast of the production of the gross regional product (GRP) (Lisin et al., 2018; Kiriyama et al., 2014; Melas et al., 2017; Osorio et al., 2017).

The regions of Russia have been challenged with ensuring the reduction of the energy intensity of the country's gross domestic product by 1.5 times by 2035 through the implementation of regional state programs for improving energy efficiency (the energy saving potential in the whole country is estimated at $40 \%$ ). Figure 3 shows the contribution of the energy intensity of the gross regional product to the energy intensity of the gross domestic product of the country.

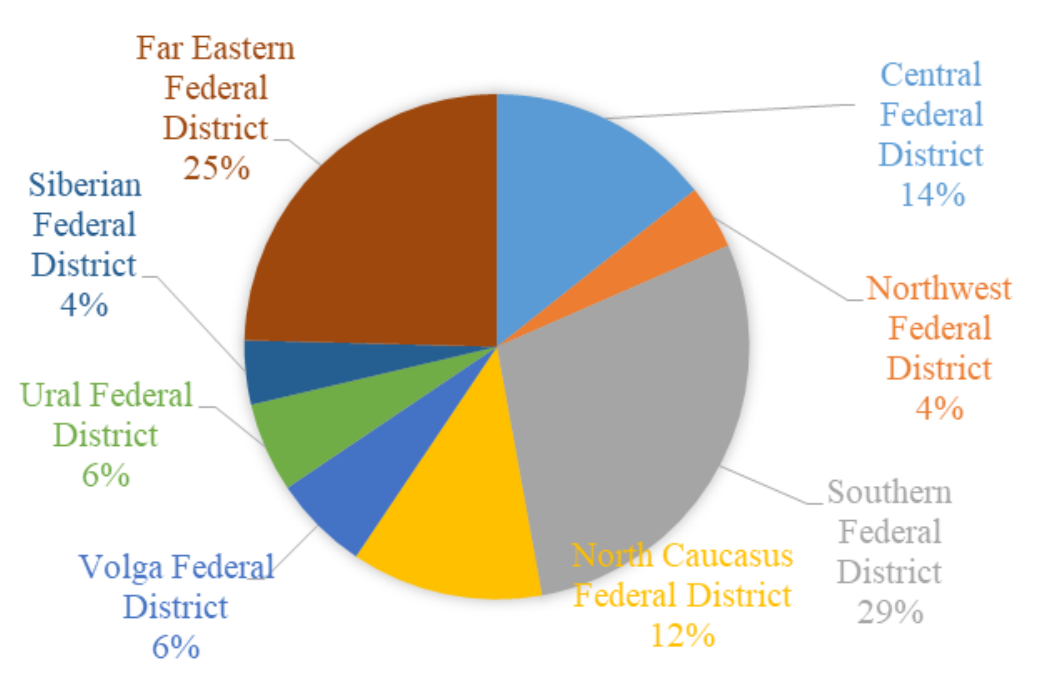

Figure 3. The contribution of the energy intensity of the gross regional product to the energy intensity of the gross domestic product of the country by federal districts

Source: own development based on (Statistical Compendium of Russian Federal Service of State Statistics, 2016)

The required reduction in the energy intensity of the GRP is achieved by the following types of strategies (Energy Strategy of Russia for the period up to 2035, 2014; Bogoviz et al., 2018; Senderov et al., 2018): 
- reducing the loss of energy resources and ensuring their energy saving in various sectors of the region's economy (primarily, the energy sector),

- increasing the growth of GRP due to the organization of low-energy production facilities, in other words, the development of small business and the services sector,

- decommissioning of old and inefficient production equipment and optimization of operating modes of the power system,

- development of energy efficient production technologies by the regional energy complex.

Production, technological and structural differences and peculiarities of regional power systems determine different priorities and scenarios for the implementation of these strategies. These differences are taken into account by the developed methodology for the typology of the energy systems of territorial entities of the country, which is based on a multidimensional statistical analysis of structural and functional indicators according to a complex model of criteria. The results of a multidimensional statistical analysis of the general power supply systems of the regions, obtained by the k-means clustering method, are presented in Table 1.

Table 1. Results of clustering of regional power supply systems

\begin{tabular}{|c|c|c|c|c|c|c|c|c|c|c|}
\hline \multirow{2}{*}{\multicolumn{3}{|c|}{ System of criteria for the power system }} & \multicolumn{8}{|c|}{ Groups of regions } \\
\hline & & & I & II & III & IV & $\mathrm{V}$ & VI & VII & VIII \\
\hline \multirow[t]{2}{*}{ External links } & \multicolumn{2}{|l|}{ absent } & + & + & & & & & & \\
\hline & \multicolumn{2}{|l|}{ present } & & & + & + & + & + & + & + \\
\hline \multirow[t]{6}{*}{ Type and origin of fuel } & \multirow{2}{*}{$\begin{array}{l}\text { transported } \\
\text { fossil fuel }\end{array}$} & gas & & & + & + & + & & & \\
\hline & & coal & & & & & & & & \\
\hline & \multirow{2}{*}{$\begin{array}{l}\text { local fossil } \\
\text { fuel }\end{array}$} & gas & + & + & & & & + & & \\
\hline & & coal & + & + & & & & + & + & + \\
\hline & \multicolumn{2}{|l|}{ nuclear fuel } & & & & & + & & & \\
\hline & \multicolumn{2}{|l|}{ hydroenergy } & + & & + & & + & + & & + \\
\hline \multirow[t]{2}{*}{ Production scheme } & \multicolumn{2}{|l|}{ combined } & + & + & + & + & + & + & + & + \\
\hline & \multicolumn{2}{|l|}{ separate } & & + & & + & & + & + & \\
\hline \multirow[t]{2}{*}{ Manufacturing capacity } & \multicolumn{2}{|l|}{ excess } & + & + & & + & + & & + & \\
\hline & \multicolumn{2}{|l|}{ shortage } & & & + & & & + & & + \\
\hline \multirow[t]{2}{*}{ Heat demand } & \multicolumn{2}{|l|}{ moderate } & & & + & + & + & & & \\
\hline & \multicolumn{2}{|l|}{ high } & + & + & & & & + & + & + \\
\hline \multirow{2}{*}{$\begin{array}{l}\text { Electrical energy consumption } \\
\text { density }\end{array}$} & \multicolumn{2}{|l|}{ low } & & & + & + & & & & + \\
\hline & \multicolumn{2}{|l|}{ high } & + & + & & & + & + & + & \\
\hline
\end{tabular}

Source: own development

The implemented typology made it possible to compile generalized characteristics of the power systems of isolated and open regions of the country. Thus, groups I and II represent the types of power supply systems of territorially isolated regions (5 subjects). Their delimiting feature is the use of renewable energy sources (primarily, hydropower) in electricity supply. With its development, the share of thermal power plants, producing only electricity, is significantly reduced. The power supply systems of open regions (80 subjects) are characterized by a much wider typification and represented by groups III - VIII:

- power supply systems of the regions of the non-production sphere of the European part of the country (19 subjects),

- power supply systems of post-industrial regions of the European part of the country (23 subjects),

- power supply systems of industrial regions of the European part of the country (15 subjects),

- power supply systems of energy-intensive industrial and raw materials regions of the Asian part of the country (11 subjects), 
The International Journal

ENTREPRENEURSHIP AND SUSTAINABILITY ISSUES

ISSN 2345-0282 (online) http://jssidoi.org/jesi/

2018 Volume 6 Number 2 (December)

http://doi.org/10.9770/jesi.2018.6.2(38)

- power supply systems of industrial regions of the Asian part of the country with a declining production scale (7 subjects),

- power supply systems of the regions of the non-production sphere of the Asian part of the country (5 subjects).

Table 2 shows the correlation of strategies for reducing the energy intensity of the GRP with the groups of region's power supply systems identified as a result of the typology carried out.

Table 2. Correlation of strategies for reducing the energy intensity of the GRP with the groups of region identified as a result of the typology carried out

\begin{tabular}{|l|l|}
\hline $\begin{array}{l}\text { Power supply } \\
\text { system group }\end{array}$ & Priority strategy for reducing energy intensity of the GRP \\
\hline I & $\begin{array}{l}\text { Development of energy-efficient production technologies to improve the efficiency and capacity utilization } \\
\text { factor of the power supply system }\end{array}$ \\
\hline II & Reducing the loss of energy resources and ensuring their energy saving in energy sector \\
\hline III, VIII & $\begin{array}{l}\text { Development of energy efficient production technologies that increase the efficiency of the power supply } \\
\text { system in the context of uneven energy consumption }\end{array}$ \\
\hline IV & Reducing the energy intensity of production due to its restructuring and development of the service sector \\
\hline V, VI & Reducing the loss of energy resources and ensuring their energy saving in energy sector \\
\hline VII & $\begin{array}{l}\text { Decommissioning of old and inefficient production equipment and optimization of operating modes of the } \\
\text { power system }\end{array}$ \\
\hline
\end{tabular}

Source: own development

As it appears from the conducted analysis, for regions with isolated power supply systems, the choice of a priority strategy for reducing the energy intensity of the GRP is largely determined by the structure of the energy sources used, primarily by the use of renewable energy sources. Whereas, for regions with open energy systems, the choice of a strategy for reducing the energy intensity depends on their economic base of sustainable growth and the state of the energy infrastructure.

\section{Conclusions}

The presented developments form an improved model for managing the development of a territorial energy complex, including current market and state instruments for managing heat and power supply systems that allow increasing the level of energy security of territorial power supply systems.

Separation of power system management (as a technical system) by individual organizational units (enterprises) based on management decomposition and feedback management allowed us to harmonize the performance criteria of management entities located at different organizational levels. In turn, the reflection of the interests of the management subjects at various organizational levels is the basis for making decisions on the development and functioning of the territorial energy supply system.

Due to the wide variety of territorial power supply systems and the presence of significant differences in their structure and operating conditions, determining the choice of their development strategy, a methodology for typologizing power systems has been developed based on conducting multidimensional statistical analysis according to a complex model of criteria. The most effective strategies for reducing energy intensity have been proposed for each selected group of power supply systems of the Russian regions. 
The International Journal

ENTREPRENEURSHIP AND SUSTAINABILITY ISSUES

ISSN 2345-0282 (online) http://jssidoi.org/jesi/

2018 Volume 6 Number 2 (December)

http://doi.org/10.9770/jesi.2018.6.2(38)

\section{Acknowledgement}

This paper was supported by the Ministry of Education and Science of the Russian Federation, research project No. 26.9593.2017/8.9

\section{References}

Ang, B. W.; Choong, W. L.; Ng, T. S. 2015. Energy security: Definitions, dimensions and indexes. Renewable and Sustainable Energy Reviews, 42: 1077-1093. https://doi.org/10.1016/j.rser.2014.10.064

Augutis, J.; Krikstolaitis, R.; Martisauskas, L.; Peciulyte, S.; Zutautaite, I. 2017. Integrated energy security assessment. Energy, 138: 890901. https://doi.org/10.1016/j.energy.2017.07.113

Balitskiy, S.; Bilan, Y.; Strielkowski, W. 2014. Energy security and economic growth in the European Union. Journal of Security \& Sustainability Issues, 4(2):125-132

Bilan, Y.; Strielkowski, W.; Karbach, R.; Mentel, G. 2017. Secure development of country and competitiveness issues: Case of Germany's energy security. Journal of Security and Sustainability Issues 6(3):329-342. http://dx.doi.org/10.9770/jssi.2017.6.3(1)

Blum, H.; Legey, F.L. 2012. The challenging economics of energy security: Ensuring energy benefits in support to sustainable development. Energy Economics 34(6): 1982-1989. https://doi.org/10.1016/j.eneco.2012.08.013

Bogoviz, A. V.; Lobova, S. V.; Ragulina, Y. V.; Alekseev, A. N. 2018. Russia's Energy Security Doctrine: Addressing Emerging Challenges and Opportunities. International Journal of Energy Economics and Policy 8(5): 1-6.

Borelli, D.; Devia, F.; Lo Cascio, E.; Schenone, C.; Spoladore, A. 2016. Combined production and conversion of energy in an urban integrated system. Energies 9(10): 817-834. https://doi.org/10.3390/en9100817

Brożyna, J.; Mentel, G.; Szetela, B.; Strielkowski, W. 2018. Multi-seasonality in the TBATS model using demand for electric energy as a case study. Economic Computation \& Economic Cybernetics Studies \& Research 52(1):229-246. https://doi.org/10.24818/18423264/52.1.18.14

Chernenko, N. 2015. Market power issues in the reformed Russian electricity supply industry. Energy Economics, 50: 315-323. https://doi.org/10.1016/j.eneco.2015.05.017

Energy Strategy of Russia. 2014. Energy Strategy of Russia for the period up to 2035 (main provisions). Available on the Internet: http://ac.gov.ru/files/content/1578/11-02-14-energostrategy-2035-pdf.pdf

Goldthau, A.; Sovacool, B. K. 2012. The uniqueness of the energy security, justice, and governance problem. Energy Policy 41: 232-240. https://doi.org/10.1016/j.enpol.2011.10.042

Hughes, L.; Ranjan, A. 2013. Event-related stresses in energy systems and their effects on energy security. Energy 59: 413-421. https://doi.org/10.1016/i.energy.2013.06.070

Kashintseva, V.; Strielkowski, W.; Streimikis, J.; Veynbender, T. 2018. Consumer Attitudes towards Industrial CO2 Capture and Storage Products and Technologies. Energies 11(10):2787. https://doi.org/10.3390/en11102787

Kiriyama, E.; Kajikawa, Y. 2014. A multilayered analysis of energy security research and the energy supply process. Applied Energy 123, 415-423. https://doi.org/10.1016/j.apenergy.2014.01.026

Li, H.; Sun, Q.; Zhang, Q.; Wallin, F. 2015. A review of the pricing mechanisms for district heating systems. Renewable and Sustainable Energy Reviews 42: 56-65. https://doi.org/10.1016/j.rser.2014.10.003 
Lisin, E.; Kindra, V.; Horvathova, Z. 2017. Sustainable development of regional heat supply systems in the context of the Eurasian economic union energy markets association. Journal of Security \& Sustainability Issues 6(4): 215-245. https://doi.org/10.9770/jssi.2017.6.4(18)

Lisin, E.; Rogalev, A.; Strielkowski, W.; Komarov, I. 2015. Sustainable modernization of the Russian power utilities industry. Sustainability 7(9): 11378-11400. https://doi.org/10.3390/su70911378

Lisin, E.; Shuvalova, D.; Volkova, I.; Strielkowski, W. 2018a. Sustainable Development of Regional Power Systems and the Consumption of Electric Energy. Sustainability 10(4): 1111-1121. https://doi.org/10.3390/su10041111

Lisin, E.; Sobolev, A.; Strielkowski, W.; Garanin, I. 2016. Thermal efficiency of cogeneration units with multi-stage reheating for Russian municipal heating systems. Energies, 9(4): 269-288. https://doi.org/10.3390/en9040269

Lisin, E.; Strielkowski, W. 2014. Modelling new economic approaches for the wholesale energy markets in Russia and the EU. Transformations in Business \& Economics 13: 566-580.

Lisin, E.; Strielkowski, W.; Chernova, V.; Fomina, A. 2018. Assessment of the Territorial Energy Security in the Context of Energy Systems Integration. Energies 11(12):3284. https://doi.org/10.3390/en11123284

Melas, V.; Lisin, E.; Tvaronavičienè, M.; Peresadko, G.; Radwański, R. 2017. Energy security and economic development: renewables and the integration of energy systems. Journal of Security \& Sustainability Issues 7(1): 133-139. https://doi.org/10.9770/jssi.2017.7.1(11)

Newbery, D.; Pollitt, M.G.; Ritz, R.A.; Strielkowski, W. 2018 Market design for a high-renewables European electricity system. Renewable and Sustainable Energy Reviews 91:695-707. https://doi.org/10.1016/j.rser.2018.04.025

Osorio, S.; van Ackere, A.; Larsen, E. R. 2017. Interdependencies in security of electricity supply. Energy 135: 598-609. https://doi.org/10.1016/i.energy.2017.06.095

Paiho, S.; Abdurafikov, R.; Hoang, H.; Kuusisto, J. 2015. An analysis of different business models for energy efficient renovation of residential districts in Russian cold regions. Sustainable cities and society 14: 31-42. https://doi.org/10.1016/j.scs.2014.07.008

Postnikov, I.; Stennikov, V.; Mednikova, E.; Penkovskii, A. 2018. Methodology for optimization of component reliability of heat supply systems. Applied Energy 227: 365-374. https://doi.org/10.1016/j.apenergy.2017.11.073

Proskuryakova, L. 2017. Energy technology foresight in emerging economies. Technological Forecasting and Social Change 119: 205210. https://doi.org/10.1016/j.techfore.2016.05.024

Rausser, G.; Strielkowski, W.; Štreimikienè, D. 2018. Smart meters and household electricity consumption: A case study in Ireland. Energy \& Environment 29(1):131-146. https://doi.org/10.1177/0958305X17741385

Razminienè, K.; Tvaronavičienė, M. 2017. Economic globalization and its' impacts on clustering, Terra Economicus, 15(2): 109-121 https://doi.org/10.23683/2073-6606-2017-15-2-109-121clustering.html

Russian Federal Service of State Statistics. 2016. Statistical Compendium of Russian Federal Service of State Statistics: Industrial production in Russia. Available from the Internet: http://www.gks.ru/free_doc/doc_2016/prom16.pdf

Salas-Fumás, V.; Rosell-Martínez, J.; Delgado-Gómez, M. 2016. Capacity, investment and market power in the economic value of energy firms. Energy Economics 53: 28-39. https://doi.org/10.1016/j.eneco.2015.05.004

Senderov, S.; Smirnova, E.; Vorobev, S. 2018. Ensuring Russia's Energy Security at the Regional Level: Methodology of Evaluation, Results and Main Trends. Energy Systems Research 1(2): 57-68.

Shakhovskaya, L.; Petrenko, E.; Dzhindzholia, A.; Timonina, V. 2018. Market peculiarities of natural gass: case of the Pacific Region. Entrepreneurship and Sustainability Issues 5(3): 555-564. https://doi.org/10.9770/jesi.2018.5.3(11)

Stennikov, V. A.; Iakimetc, E. E. 2016. Optimal planning of heat supply systems in urban areas. Energy 110: 157-165. https://doi.org/10.1016/i.energy.2016.02.060

Štreimikienè, D.; Strielkowski, W.; Bilan, Y.; Mikalauskas, I. 2016. Energy dependency and sustainable regional development in the Baltic states: A review. Geographica Pannonica 20(2):79-87. https://doi.org/10.5937/GeoPan1602079S 
The International Journal

ENTREPRENEURSHIP AND SUSTAINABILITY ISSUES

ISSN 2345-0282 (online) http://jssidoi.org/jesi/

2018 Volume 6 Number 2 (December)

http://doi.org/10.9770/jesi.2018.6.2(38)

Strielkowski, W.; Lisin, E.; Astachova, E. 2017. Economic sustainability of energy systems and prices in the EU. Entrepreneurship and Sustainability Issues 4(4): 591-600. https://doi.org/10.9770/jesi.2017.4.4(14)

Strielkowski, W.; Lisin, E.; Tvaronavičienè, M. 2016. Towards energy security: sustainable development of electrical energy storage. Journal of Security and Sustainability Issues 6(2): 43-52. http://dx.doi.org/10.9770/jssi.2016.6.2(4)

Tvaronavičienė, M. 2017. Clusters, innovations and energy efficiency: if relantionship could be traced. Marketing and Management of Innovations 2: 382 - 391 http://doi.org/10.21272/mmi.2017.2-35

Tvaronavičienè, M. 2018. Towards sustainable and secure development: energy efficiency peculiarities in transport sector. Journal of Security and Sustainability Issues 7(4): 719-725. https://doi.org/10.9770/jssi.2018.7.4(9)

Wüstenhagen, R.; Wolsink, M.; Bürer, M. J. 2007. Social acceptance of renewable energy innovation: An introduction to the concept. Energy policy 35(5):2683-2691. https://doi.org/10.1016/j.enpol.2006.12.001

\section{Acknowledgements}

This paper was supported by the Ministry of Education and Science of the Russian Federation, research project No. 26.9593.2017/8.9.

\section{Authors}

Dr. Evgeny LISIN is an Accosiate Professor in the Department of Economics in Power Engineering and Industry at the National Research University "Moscow Power Engineering Institute". His main research and teaching areas are energy economics, regional energy security, sustainable development of energy systems in market conditions, entrepreneurial activities of energy companies.

ORCID ID: https://orcid.org/0000-0001-9794-913X

Dr. Galina KURDIUKOVA is a Head of Department of Economics in Power Engineering and Industry at the National Research University "Moscow Power Engineering Institute". Her main research and teaching areas are energy economics, thermal power plants, cogeneration heat and power, district heating, electricity markets.

ORCID ID: https://orcid.org/0000-0001-6524-1524

Dr. Natalya KETOEVA is a Head of Department of Management in Power Engineering and Industry at the National Research University "Moscow Power Engineering Institute". Her main research and teaching areas are organization of management of the electric power complex, management structures of energy enterprises, energy reform, energy efficiency and energy saving.

ORCID ID: $\underline{\text { https://orcid.org/0000-0001-6652-522X }}$

Dr. Joana KATINA is an Assistant Professor in the Department of Computational and Data Modeling in Institute of Computer Science in Vilnius University. Her main research and teaching areas are computational and data modeling, algorithms and data structures.

ORCID ID: $\underline{\text { https://orcid.org/0000-0002-0715-1675 }}$

Register for an ORCID ID:

https://orcid.org/register

Copyright (C) 2018 by author(s) and VsI Entrepreneurship and Sustainability Center

This work is licensed under the Creative Commons Attribution International License (CC BY).

http://creativecommons.org/licenses/by/4.0/

CC) (i) Open Access 